\title{
Extracts of Rehmanniae radix, Ginseng radix and Scutellariae radix improve glucose-stimulated insulin secretion and $\beta$-cell proliferation through IRS2 induction
}

\author{
Sun Min Park · Sang Mee Hong $\cdot$ So Ra Sung • \\ Ji Eun Lee · Dae Young Kwon
}

Published online: 20 November 2007

(C) Springer-Verlag 2007

\begin{abstract}
Recent studies have revealed that $\beta$-cell dysfunction is an important factor in developing type 2 diabetes. $\beta$-cell dysfunction is related to impairment of the insulin/ IGF-1 signaling cascade through insulin receptor substrate-2 (IRS2). The induction of IRS2 in $\beta$-cells plays an important role in potentiating $\beta$-cell function and mass. In this study, we investigated whether herbs used for treating diabetes in Chinese medicine-Galla rhois, Rehmanniae radix, Machilus bark, Ginseng radix, Polygonatum radix, and Scutellariae radix - improved IRS2 induction in rat islets, glucose-stimulated insulin secretion and $\beta$-cell survival. $R$. radix, Ginseng radix and $S$. radix significantly enhanced glucose-stimulated insulin secretion compared to the control, i.e., by 49, 67 and 58\%, respectively. These herbs induced the expression of IRS2, pancreas duodenum homeobox-1 (PDX-1), and glucokinase. The increased level of glucokinase could explain the enhancement of glucosestimulated insulin secretion with these extracts. Increased PDX-1 expression was associated with $\beta$-cell proliferation, which was consistent with the cell viability assay. In conclusion, $R$. radix, Ginseng radix and $S$. radix had an insulinotropic action similar to that of exendin-4.
\end{abstract}

Keywords Rat islets · IRS2 - Insulin secretion · $\beta$-cell proliferation $\cdot$ Diabetes

S. M. Park $(\bowtie) \cdot$ S. M. Hong · S. R. Sung · J. E. Lee

Department of Food and Nutrition, College of Natural Science, Hoseo University, 165 Sechul-ri, Baebang-myun, Asan-si, Chungchongnam-do 336-795, Republic of Korea

e-mail:smpark@hoseo.edu

D. Y. Kwon

Division of Food Functional Research, Korean Food Research Institutes, Songnam, Kyoungki-do 463-746, Republic of Korea

\section{Introduction}

Insulin resistance and $\beta$-cell dysfunction lead to type 2 diabetes [1]. Insulin resistance and diabetes increase the incidence of metabolic disorders such as diabetes, hypertension, dyslipidemia, obesity, stroke, retinopathy, myocardial infarction and neurodegeneration [1]. $\beta$-Cell dysfunction, which is associated with modulation of $\beta$-cell mass, is an important factor in developing type 2 diabetes $[5,16]$. The dysfunction is related to impairment of the insulin/IGF-1 signaling cascade [8, 18]. Insulin receptor substrate 2 (IRS2) is the primary and predominate protein delivering insulin/insulin like growth factor-1 (IGF-1) signaling in pancreatic $\beta$-cells [18]. The pleckstrin homology $(\mathrm{PH})$ and phosphotyrosine-binding (PTB) domains of IRS2 bind to phosphorylated insulin receptor upon binding of insulin or IGF-1 to their receptors. Phosphorylated IRS2 protein binds to and activates phosphatidylinositol 3 (PI3) kinase. PI3 kinase sends signals into several different pathways [18], resulting in increased cellular growth, antiapoptosis and protein synthesis in $\beta$-cells. Thus, IRS 2 is an important protein in $\beta$-cell growth and survival.

Most studies aimed at determining the role of IRS2 have been performed in gene-manipulated mice [8, 18]. Mice overexpressing IRS2 in $\beta$-cells were found to improve glucose homeostasis by enhancing glucose-stimulated insulin secretion [8]. However, this cannot be applied to physiological conditions. The question was raised whether IRS2 induction occurs under physiological conditions. White [17] found evidence that a cAMP responding element (CRE) site exits upstream of the IRS2 coding region in humans and mice [15]. Several studies have shown that CRE binding protein (CREB) activation increases IRS2 expression [10, 15]. Exendin-4, a glucagon-like peptide-1 (GLP-1) receptor agonist originally extracted from lizard 
venom, increased IRS2 levels in islets through elevated intracellular cAMP levels [15]. GLP-1/exendin-4 is known to enhance glucose-stimulated insulin secretion and to increase $\beta$-cell transcription factors, such as pancreas duodenum homeobox-1 (PDX-1), to promote $\beta$-cell growth and survival $[4,15]$. These actions of exendin- 4 were associated with IRS2 induction. Thus, IRS2 pathways play an important role in $\beta$-cell expansion, which is required to elevate insulin secretion to overcome hyperglycemia. In this study, we investigated whether six herbs used for treating diabetes in Chinese medicine improved IRS2 induction in rat islets, glucose-stimulated insulin secretion, and $\beta$-cell survival. The herbs used were Galla rhois, Rehmanniae radix (Rehmannia glutinosa LIBOSCHITZ var. purpurea MAKING), Machilus bark (Machilus thynbergii SIEBOLD et ZUCCARINI), Polygonatum radix (Polygonatum odoratum Miller Druce), Ginseng radix (Panax ginseng C.A. MEYER), and Scutellariae radix (Scutellariae baicalensis GEORGI).

\section{Materials and methods}

Herb extraction

Galla rhois, Rehmannia radix, Machilus bark, Ginseng radix, Polygonatum radix, and Scutellariae radix were each extracted with $70 \%$ ethanol at $50^{\circ} \mathrm{C}$ for $12 \mathrm{~h}$. The extracts were filtered through a $0.4 \mu \mathrm{m}$ filter, and concentrated by vacuum evaporation and lysophilization. The powder was dissolved in sterile dimethyl sulfoxide (DMSO; Sigma, St. Louis, MO) to $1 \mathrm{mg} / \mathrm{ml}$, and then further diluted with sterile phosphate buffered saline or medium to the required concentration.

Glucose-stimulated insulin secretion in islets

Pancreatic islets from male rats were isolated by collagenase digestion as previously described $[8,15]$, and then incubated for $24 \mathrm{~h}$ in high glucose Dulbecco's modified Eagles medium (DMEM) containing 10\% (v/v) heatinactivated fetal bovine serum, $50 \mu \mathrm{M} \beta$-mercaptoethanol, penicillin and streptomycin at $37^{\circ} \mathrm{C}$ in a humidified atmosphere with $5 \% \mathrm{CO}_{2}$ to allow recovery from the isolation process and to eliminate acinar cells. Twenty islets were pre-incubated with low glucose DMEM containing $5 \mathrm{mg} / \mathrm{ml}$ bovine serum albumin (BSA) for $16 \mathrm{~h}$ in order to recover condition following the digestion process. The islets were treated with the vehicle (DMSO) or designated concentrations of each herb extract in low $(2 \mathrm{mM})$ or high glucose $(20 \mathrm{mM})$ Krebs-Ringer buffer containing $20 \mathrm{mM}$ Hepes (pH 7.4) and $5 \mathrm{mg} / \mathrm{ml} \mathrm{BSA} \mathrm{for}$
$30 \mathrm{~min}$. Insulin concentrations for each medium were measured from the low and high glucose media using a radioimmunoassay kit (Linco Research, St. Charles, MO). Exendin-4 (2.5 nM) was used as a positive control. Cell viability was measured with a WST-1 colorimetric assay kit (Roche, Basel, Switzerland) at 6, 12 and $36 \mathrm{~h}$ as each herb extract was treated for $36 \mathrm{~h}$. These experiments were repeated four times.

\section{Quantitative RT-PCR}

Eighty recovered islets were treated with DMSO or each herb extract for $8 \mathrm{~h}$. Total RNA was isolated from control (DMSO-treated) or extract-treated islets with Trizol (GIBCO BRL, Life Technologies, Grand Island, NY). cDNA synthesis was performed with a RETROscript kit (Ambion, Austin, TX) using oligo dT. Quantitative RT-PCR was then carried out using a QuantiTect SYBR Green PCR kit (Qiagen, Valencia, CA) on an iCycler PCR instrument (BioRad Laboratories, Hercules, CA). The PCR reactions were performed following the kit manual. The following primers were used for the mice insulin receptor substrate (IRS)-2, PDX-1, glucokinase and cyclophilin genes:

IRS2 forward:

5'-CATCGACTTCCTGTCCCAT CA-3',

IRS2 reverse: 5'-CCCATCCTCAAGGTCAAA GG- $3^{\prime}$;

PDX-1 forward: $\quad 5$-AGGAAAACAAGAGGACCC GTACT-3',

PDX-1 reverse: $\quad 5^{\prime}$-CGGGAGATGTATTTGTTAA ATAAGAATTC- $3^{\prime}$;

Glucokinase forward: 5 -CCTGAGGCTGGAGACCCA TGA- $3^{\prime}$,

Glucokinase reverse: $\quad 5^{\prime}$-TGGGGTGGAGCGCACGT A- $3^{\prime}$;

Cyclophilin forward: $5^{\prime}$-CAGACGCCACTGTCGCTT $\mathrm{T}-3^{\prime}$,

Cyclophilin reverse: $\quad 5^{\prime}$-TGTCTTTGGAACTTTGTCT GCAA- $3^{\prime}$.

The relative quantification analysis was performed by calculating the ratio of the PCR product of the gene of interest to that of internal control cyclophilin.

Statistical analysis

All results are expressed as mean \pm SD. Statistical analysis was performed using the SAS program. Two sample $t$-test was carried out to determine the significant difference between the control (DMSO) and each herb extract. Results of $P<0.05$ were considered statistically significant. 


\section{Results and discussion}

Glucose-stimulated insulin secretion in islets

Insulin secretion in islets isolated from rats increased by $4.0 \pm 0.5$-fold in high glucose $(20 \mathrm{mM})$ DMEM medium compared to low glucose (2 mM) medium. Galla rhois, Rehmanniae radix, Machilus bark, Polygonatum radix, Ginseng radix and Scutellariae radix did not alter the insulin secretion in low glucose medium (Fig. 1). However, in high glucose medium $(20 \mathrm{mM}), 50 \mu \mathrm{g} / \mathrm{ml} R$. radix, Ginseng radix and $S$. radix significantly enhanced glucosestimulated insulin secretion compared to the control, by 49 , 67 and $58 \%$, respectively (Fig. 1), although the increase did not reach the same level as with $2.5 \mathrm{nM}$ exendin-4 treatment.

Treatment with exendin-4, a GLP-1 agonist, enhances glucose-stimulated insulin secretion in rodents and humans. Human studies have shown that extended administration of GLP-1 not only augments glucose-stimulated insulin secretion, but also shifts the dynamics of the insulin response to earlier release in both diabetic and nondiabetic humans [2, 9]. The mechanism was revealed as acting directly through the cAMP/protein kinase A (PKA) pathway to enhance and sensitize $\beta$-cells to glucose-stimulated insulin secretion. Activated PKA may close $\mathrm{K}_{\mathrm{ATP}}$ channels, and activate $\mathrm{Ca}^{2+}$ channels and exocytosis of insulin containing granules [3]. GLP-1 also increases insulin secretion in a calcium- and PKA-independent manner by mobilizing secretory vesicles to enter the readily releasable pool [6]. $R$. radix, Ginseng radix and

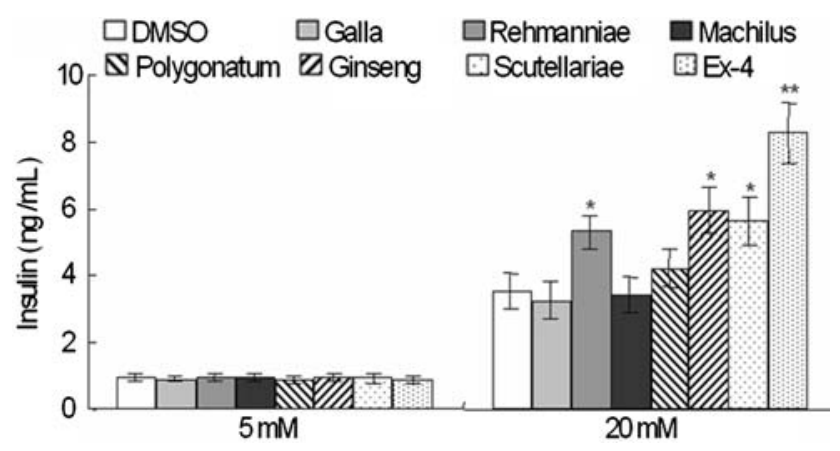

Fig. 1 Glucose-stimulated insulin secretion in isolated rat islets. After $16 \mathrm{~h}$ incubation in low glucose Dulbecco's modified Eagles medium (DMEM), isolated mice isles were treated with vehicle [dimethylsulfoxide (DMSO], $50 \mu \mathrm{g} / \mathrm{ml}$ extracts of Galla rhois, Rehmanniae radix, Machilus bark, Ginseng radix, Polygonatum radix or Scutellariae radix, or $2.5 \mathrm{nM}$ exendin-4 (positive control) in low glucose $(5 \mathrm{mM})$ or high glucose $(20 \mathrm{mM})$ Krebs-Ringer buffer for $30 \mathrm{~min}$ to measure glucose stimulated insulin secretion. These assays were repeated four times, and the results were expressed as mean \pm SD. Asterisks indicate significant differences from the control (DMSO-treated) group in two-sample $t$-test at $P<0.05$
$S$. radix may enhance glucose-stimulated insulin secretion through cAMP/PKA-dependent and/or -independent pathways. No studies have examined whether $R$. radix, Ginseng radix, $S$. radix or their components modulate insulin secretion through the cAMP/PKA pathway in islets. However, accumulating evidence indicates that ginsenosides-major components of ginseng-modulate the release of neurotransmitters in neuronal cells through the cAMP/PKA pathway [19]. Ginsenoside Rb1 promotes neurotransmitter release by increasing the phosphorylation of synapsins through PKA-pathway-activated neurotransmission [19]. In addition, ginsenoside $\mathrm{Rb} 1$ and the lipophilic fraction of ginseng increase intracellular cAMP in liver and platelets, respectively [13, 14]. Baicalein, a major flavonoid derived from $S$. radix, was also found to potentiate $\mathrm{Ca}^{2+}$-mediated $\mathrm{Cl}^{-}$secretion through a signaling pathway involving cAMP and protein kinase $\mathrm{A}$ in the apical membrane of intestinal epithelial cells [20]. Thus, $R$. radix, Ginseng radix and $S$. radix may enhance glucosestimulated insulin secretion in $\beta$-cells through a cAMPmediated pathway.

mRNA levels of IRS2, PDX-1, and glucokinase islets

We indirectly determined the involvement of a cAMPmediated pathway in $\beta$-cells by measuring mRNA levels of IRS2, which is known to be induced by cAMP $\rightarrow$ CREB phosphorylation. Rat islets were incubated with each herb extract for $8 \mathrm{~h}$, and IRS2 mRNA levels were determined (Fig. 2). Previous studies had revealed that induction of IRS2 results in improved glucose sensing and $\beta$-cell proliferation through enhancing insulin/IGF-1 signaling in islets [8, 15]. Expression of PDX-1 and glucokinase was associated with glucose sensing and $\beta$-cell proliferation, respectively $[7,11,12]$. Thus, levels of PDX-1 and glucokinase mRNA were also measured in islets treated with herb extracts (Fig. 2). In parallel with enhanced glucose-stimulated insulin secretion, $R$. radix, Ginseng radix and $S$. radix induced increased levels of PDX-1 and glucokinase mRNA in islets, indicating that the insulin/IGF-1 signaling cascade was enhanced through increased IRS2 levels.

In islets, glucokinase acts as a glucose sensor to utilize glucose to generate ATP and close the $\mathrm{K}_{\mathrm{ATP}}$ channel, resulting in efficient insulin secretion when serum glucose is elevated [12]. In addition, elevated PDX-1 expression is known to result in insulin/IGF-1 signaling and to potentiate $\beta$-cell proliferation [15]. Thus, induction of IRS2, PDX-1, and glucokinase expression promotes $\beta$-cell growth and function to regulate glucose-stimulated insulin secretion. Our previous study showed that exendin-4, a peptide derived from lizard venom, enhanced glucose-stimulated insulin secretion and $\beta$-cell proliferation through induction 


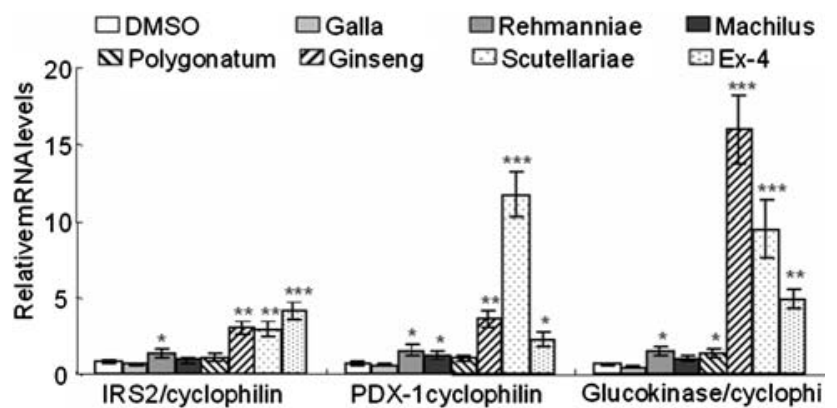

Fig. 2 Expression of insulin receptor substrate 2 (IRS2), pancreas duodenum homeobox-1 (PDX-1), and glucokinase mRNAs in islets isolated from rats. Isolated islets were administered with vehicle (DMSO), $50 \mu \mathrm{g} / \mathrm{ml}$ extracts of Galla rhois, R. radix, M. bark, Ginseng radix, $P$. or $S$. radix, or $2.5 \mathrm{nM}$ exendin- 4 in high glucose DMEM medium for $8 \mathrm{~h}$. Total RNA extracted from islets was reverse transcribed to make cDNA, and mRNA levels of IRS2, PDX-1, glucokinase and cyclophilin were measured by realtime PCR using primer sets for the full length of IRS2, PDX-1, glucokinase and cyclophilin genes. The results are presented as the ratio of mRNA levels of the gene of interest (IRS2, PDX-1 and glucokinase) to those of a housekeeping gene (cyclophilin). Asterisks indicate significant differences from the control (DMSO-treated) group in two-sample $t$ test at $P<0.05$

of IRS2 [8, 15]. Through this enhancement, exendin-4 improves glucose homeostasis in animals and humans. To investigate whether increased PDX-1 expression improves $\beta$-cell proliferation, cell viability was measured in isolated islets treated with herb extracts. Cell viability, as measured by WST-1 assay, decreased with DMSO treatment over time. $R$. radix, Ginseng radix and $S$. radix improved cell viability at $6 \mathrm{~h}$ and after that, delayed the decrease in cell viability (Fig. 3).

In conclusion, extracts of Rehmanniae radix, Ginseng radix and Scutellariae radix enhanced glucose-stimulated insulin secretion by improving glucose sensing through

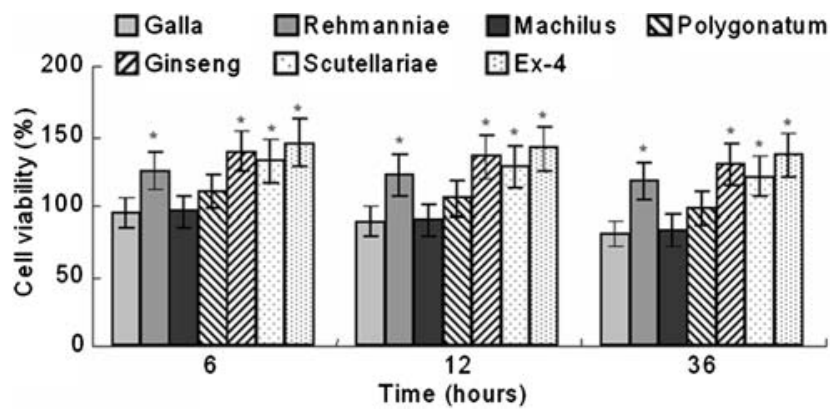

Fig. 3 Cell viability of islets isolated from rats. After isolated islets were administered with vehicle (DMSO), $50 \mu \mathrm{g} / \mathrm{ml}$ extracts of Galla Rhois, Rehmanniae radix, $M$. bark, Ginseng radix, Polygonatum radix or Scutellariae radix, or $2.5 \mathrm{nM}$ exendin-4 in high glucose DMEM media, cell viability was measured with a WST-1 assay kit at 6,12 and $36 \mathrm{~h}$. These experiments were repeated four times, and the results were expressed as mean $\pm \mathrm{SD}$. Asterisks are significantly different from the control (DMSO-treated) group in two-sample $t$-test at $P<0.05$ increased glucokinase expression. In addition, they increased IRS2 induction to elevate $\beta$-cell proliferation through the induction of PDX-1 via potentiating insulin/ IGF-1 signaling. Thus, these extracts contain candidates for an insulinotropic agent like exendin-4.

Acknowledgment This work was supported by a grant from the Korea Research Foundation in Korea (KRF-2005-041-C00510); BioFood Research Program, Ministry of Science and Technology.

\section{References}

1. Abdul-Ghani MA, Tripathy D, DeFronzo RA (2006) Contributions of beta-cell dysfunction and insulin resistance to the pathogenesis of impaired glucose tolerance and impaired fasting glucose. Diabetes Care 29:1130-1139

2. Alarcon C, Wicksteed B, Rhodes CJ (2006) Exendin 4 controls insulin production in rat islet beta cells predominantly by potentiation of glucose-stimulated proinsulin biosynthesis at the translational level. Diabetologia 49:2920-2929

3. Beguin P, Nagashima K, Gonoi T, Shibasaki T, Takahashi K, Kashima Y, Ozaki N, Geering K, Iwanaga T, Seino S (2001) Regulation of $\mathrm{Ca}^{2+}$ channel expression at the cell surface by the small G-protein kir/Gem. Nature 411:701-706

4. Buteau J, Roduit R, Susini S, Prentki M (1999) Glucagon-like peptide-1 promotes DNA synthesis, activates phosphatidylinositol 3-kinase and increases transcription factor pancreatic and duodenal homeobox gene 1 (PDX-1) DNA binding activity in beta (INS-1)-cells. Diabetologia 42:856-864

5. Chiasson JL, Rabasa-Lhoret R (2004) Prevention of type 2 diabetes: insulin resistance and beta-cell function. Diabetes 53:S34 S38

6. Doyle ME, Egan JM (2003) Pharmacological agents that directly modulate insulin secretion. Pharmacol Rev 55:105-131

7. Efanov AM, Barrett DG, Brenner MB, Briggs SL, Delaunois A, Durbin JD, Giese U, Guo H, Radloff M, Gil GS, Sewing S, Wang Y, Weichert A, Zaliani A, Gromada J (2005) A novel glucokinase activator modulates pancreatic islet and hepatocyte function. Endocrinology 146:3696-3701

8. Hennige AM, Burks DJ, Ozcan U, Kulkarni RN, Ye J, Park S, Schubert M, Fisher TL, Dow MA, Leshan R, Zakaria M, MossaBasha M, White MF (2003) Upregulation of insulin receptor substrate-2 in pancreatic beta cells prevents diabetes. J Clin Invest 112:1521-1532

9. Iltz JL, Baker DE, Setter SM, Campbell RK (2006) Exenatide: an incretin mimetic for the treatment of type 2 diabetes mellitus. Clin Ther 28:652-665

10. Jhala US, Canettieri G, Screaton RA, Kulkarni RN, Krajewski S, Reed J, Walker J, Lin X, White MF, Montminy M (2003) cAMP promotes pancreatic beta-cell survival via CREB-mediated induction of IRS2. Genes Dev 17:1575-1580

11. Kulkarni RN, Jhala US, Winnay JN, Krajewski S, Montminy M, Kahn CR (2004) PDX-1 haploinsufficiency limits the compensatory islet hyperplasia that occurs in response to insulin resistance. J Clin Invest 114:828-836

12. Otani K, Kulkarni RN, Baldwin AC, Krutzfeldt J, Ueki K, Stoffel M, Kahn CR, Polonsky KS (2004) Reduced beta-cell mass and altered glucose sensing impair insulin-secretory function in betaIRKO mice. Am J Physiol Endocrinol Metab 286:E41-E49

13. Park HJ, Lee JH, Song YB, Park KH (1996) Effects of dietary supplementation of lipophilic fraction from Panax ginseng on cGMP and cAMP in rat platelets and on blood coagulation. Biol Pharm Bull 19:1434-1439 
14. Park KH, Shin HJ, Song YB, Hyun HC, Cho HJ, Ham HS, Yoo YB, Ko YC, Jun WT, Park HJ (2002) Possible role of ginsenoside $\mathrm{Rb} 1$ on regulation of rat liver triglycerides. Biol Pharm Bull 25:457-460

15. Park S, Dong X, Fisher TL, Dunn SL, Omer AK, Weir G, White MF (2006) Exendin-4 promotes IRS2 signaling to mediate pancreatic beta-cell growth and function. J Biol Chem 281:11591168

16. Weir GC, Bonner-Weir S (2004) Five stages of evolving beta-cell dysfunction during progression to diabetes. Diabetes 53:S16-S21

17. White MF (1998) The IRS-signaling system: a network of docking proteins that mediate insulin action. Mol Cell Biochem 182:3-11
18. Wither DJ, Gutierrez JS, Towery H, Burks DJ, Ren JM, Previs S, Zhang Y, Bernal D, Pons S, Shulman GI, Bonner-Weir S, White MF (1998) Disruption of IRS-2 causes type 2 diabetes in mice. Nature 391:900-904

19. Xue JF, Liu ZJ, Hu JF, Chen H, Zhang JT, Chen NH (2006) Ginsenoside $\mathrm{Rb} 1$ promotes neurotransmitter release by modulating phosphorylation of synapsins through a cAMP-dependent protein kinase pathway. Brain Res 1106:91-98

20. Yue GG, Yip TW, Huang Y, Ko WH (2004) Cellular mechanism for potentiation of $\mathrm{Ca}^{2+}$-mediated $\mathrm{Cl}^{-}$secretion by the flavonoid baicalein in intestinal epithelia. J Biol Chem 279:39310-39316 